\title{
ABSTRACT \\ Meaning in the Weaving: Mapping and Texture as \\ Figures of Spatiality and Eventness
}

Advocating a dramaturgical ontology of events rather than objects - or ecologies rather than cartographies - the article defends the metaphors of texture and weaving as intuitive, non-anthropocentric alternatives to current idioms of becoming and emergence. Already popularized as the very definition of "dramaturgy" by Eugenio Barba, these are specifically traced through Tim Ingold's recent anthropology of weaving and S. C. Pepper's philosophical pragmatism: where Ingold's ecology of lines admits to "no insides or outsides [...] trailing loose ends in every direction", Pepper's "contextualistic world" of events admits "no top nor bottom" to its strands and textures. Intended only as a theoretical introduction to the implications of a certain family of metaphors (complete with a graphic representation thereof), this article distinguishes the eventness of texture from certain notions of spatial "mapping" and discusses the "ecological" range of the metaphor through the concepts of textural fusion and spread.

Keywords: dramaturgy, ecology, metaphor, texture, weaving, Tim Ingold, Stephen C. Pepper.

BIOGRAPHY

Teemu Paavolainen is a postdoctoral researcher at the Centre for Practice as Research in Theatre, University of Tampere. His Theatre/Ecology/Cognition: Theorizing Performer-Object Interaction in Grotowski, Kantor, and Meyerhold was

published by Palgrave Macmillan in 2012. He is currently finishing another research monograph. Work on this project was enabled by a three-year postdoctoral funding from the Academy of Finland in 2012-15, also to be acknowledged for the writing of this article. The full manuscript is to be completed in 2016 and is tentatively titled Texture: Theatricality and Performativity from a Dramaturgical

Perspective.

Teemu.Paavolainen@uta.fi 


\section{Meaning in the Weaving: Mapping and Texture as Figures of Spatiality and Eventness}

\section{TEEMU PAAVOLAINEN}

\section{DRAMATURGIES OF SEQUENCE AND SATURATION}

Most generally, "dramaturgy" arguably concerns the organization of materials, or the work of actions both derived from the Greek ergon (cf. organism, ergonomics). To the extent that "all theories of organization" reflect "implicit images or metaphors that lead us to see, understand, and manage organizations in distinctive yet partial ways", as Gareth Morgan has argued in the distinct field of organization studies, ${ }^{1}$ a few recurrent metaphors also seem to organize our understandings of dramatic organization. Of those discussed by Morgan, Cathy Turner and Synne K. Behrndt find the mechanistic metaphor of dramaturgy appropriate to Gotthold Ephraim Lessing's approach, "rooted in the scientific revolution" in "laying bare the mechanics of dramatic composition", ${ }^{2}$ while the organic image may conceivably be traced all the way from Aristotle to Eugenio Barba. Where the former likens tragedy to the most "beautiful" of animals, of a magnitude "easily embraced in one view", the latter would dub performance as well "a living organism", and dramaturgy an "anatomical investigation" into "its different organs and layers". ${ }^{3}$ Altogether, if performance analysis "implies a sense of unravelling the different strands of a work" or event (as per its Greek root "to unloose" cited by Turner and Behrndt), ${ }^{4}$ then dramaturgy rather serves to trace their interconnection - whether understood in terms of architecture or orchestration; the design and determinism of machinery; the planting of a plant or the anatomy of an organism; or the rules and patterns of form or structure.
In theatrical tradition, however, the rich texture of any performative event is often abstracted into the rising and falling progression of one single line of action, composed of subsidiary events of change and reversal, over nested segments of dramatic time. In line with anthropologist Tim Ingold's charming study of Lines, one implicit assumption in how this is usually graphed is that lines are prototypically straight - a quality he argues modern thought has variously related with mind, masculinity and culture, as opposed to the more deviant linearities of matter, femininity and nature. ${ }^{5}$ What is more, and equivalent to reducing the eventness of dramaturgy to the "event-full" events of dramatic complication, such rigid linearity also translates their temporal articulation into a spatial sequence of points along the line thus outlined. As geographer Doreen Massey puts it, such "spatial framing is a way of containing the temporal", as indeed the very idea of "mapping things out" is utterly dependent on "holding the world still" for structural analysis. Yet as she continues, "the map is not the territory", nor is the path "a static instantaneity": where maps and graphs imply "a coherent closed system" of which the observer remains "outside and above", the "instantaneously interconnected" space they help visualize may have little to do with how space is enacted as an "openended interweaving of a multiplicity of trajectories". ${ }^{6}$

Ingold likewise recognizes a globalizing ambition in modern cartography, "looking down upon [the world-as-map] from 'up above"” while pushing "into the wings" the very "practices and itineraries 
that contributed to its production". "Much as in a child's join-the-dots puzzle", the pattern of its points-as-locations is "already given as a virtual object from the outset", while joining them up merely amounts to "a process of construction or assembly" - and once that is complete, "there is nowhere further for the line to go". ${ }^{8}$

So, suppose we imagine dramaturgy not on the model of the assembly line but rather as an assembly of lines - of divergent actions and materials that bring forth a meaningful event in their very interweaving, rather than any one of them being prioritized as an overriding sign vehicle for carrying forward a message. This duality immediately evokes two roughly concurrent, powerful models of dramaturgy that I need to cite as an important inspiration for the metaphors elaborated in this article. The first are Richard Schechner's images of the chain and the braid (see Figure 1) for arguably "Greek" and "Indian" performance traditions: in the one, "all theatrical 'effects' or 'elements' serve the driving idea, the causal chain", in the other, "the performance bunches and relaxes" with "many or few strands operating at any moment". ' Second is then the hugely influential, dual vision of weaving by means of whose tensions Eugenio Barba argues the dramaturgical "work of actions" come alive as "texture". For him, "the interweaving by means of concatenation and the interweaving by means of simultaneity" are equally important even if the latter is often considered merely "ornamental" (as if its strands were "not woven together: in the background"). ${ }^{10}$

Add to these the above distinctions between spatial mapping and temporal becoming - in Figure 1, these are simply graphed as space and event, under the heading of Context - and we have at hand a general contrast of overt structure and covert texture that would seem to undermine overly mechanistic conceptions of making altogether. As Ingold again suggests, "to emphasise making is to regard the object as the expression of an idea; to emphasise weaving is to regard it as the embodiment of a rhythmic movement [...] as truly generative [...] rather than merely revelatory of an object that is already present, in an ideal, conceptual or virtual form, in advance of the process that discloses it". ${ }^{11}$ In slightly different terms, if text, as a paradigm for dramaturgy, goes for the linear and hierarchical - the symbolic economy of print culture and sequential information processing - then texture goes for the simultaneous and heterogeneous: a performative ecology of interweaving trajectories, from which categorical boundaries of dramatic action can only ever be derived as retrospective abstractions.

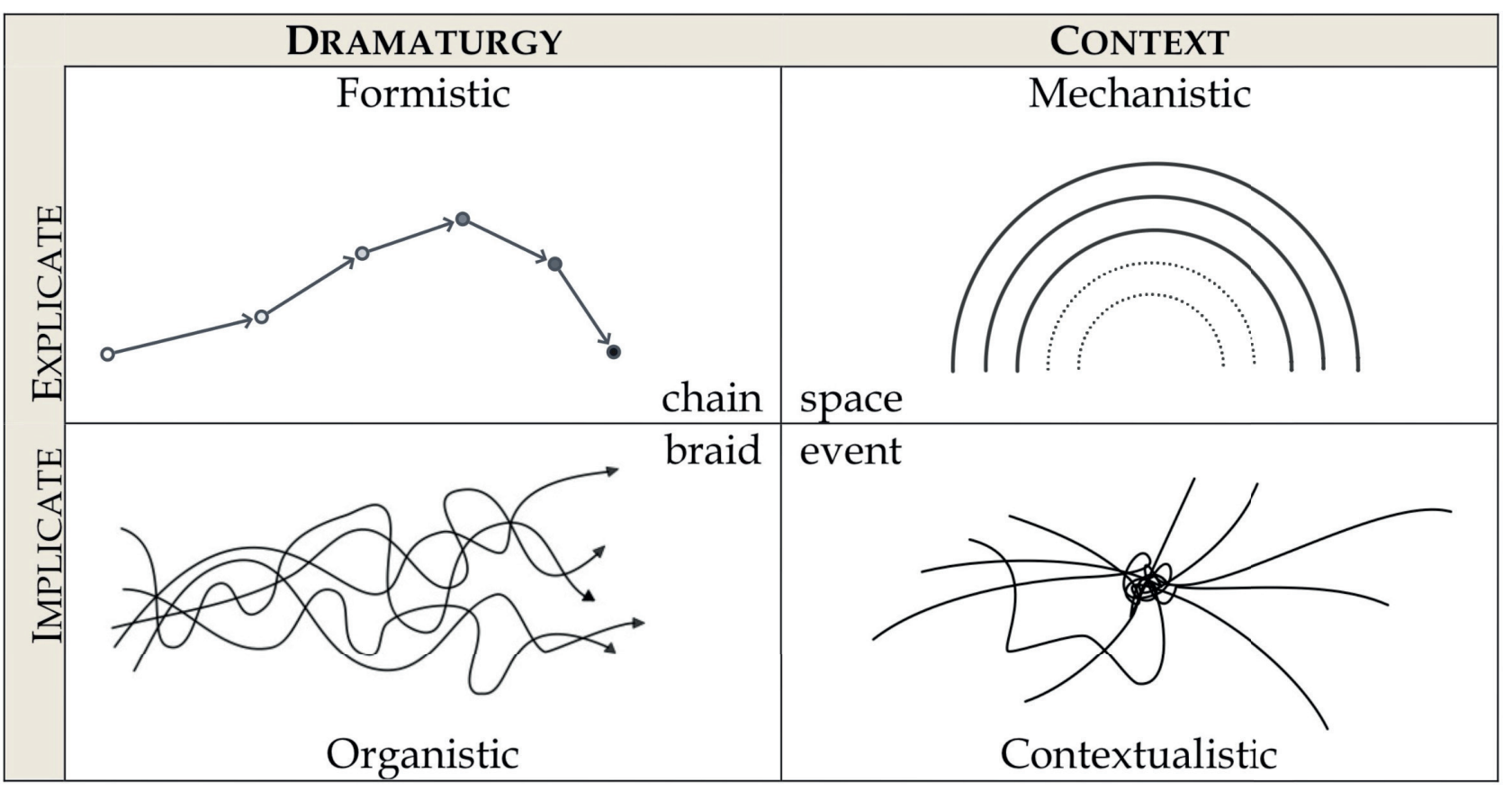

Fig. 1. Four possible models of dramaturgy and context: chain and braid are inspired by Richard Schechner, space and event by Willmar Sauter and Tim Ingold. 
Obviously, this is no grand discovery. While perhaps popularized as a definition of dramaturgy by Barba, the figure of weaving characterizes much of its current theorization ${ }^{12}$ to the effect that dramaturgy now appears less a function of the dramaturg as an isolated agent or outside eye, than of the wider ecology (weave or texture) of the performative event: "an expanded field", as Claire MacDonald puts it, which is "no longer confined to an identified person with a role, but a practice to which participants contribute". As she elaborates, such "new dramaturgy is a mediating process par excellence, both the 'weave' [...] and the process of weaving"; it is a practice "able to connect, thread, weave and perhaps to 'curate' the new ecologies of performance", holding together the "strands that emerge" such that "the context itself becomes dramaturgically charged". ${ }^{13}$ In Bruce Barton's words, the transition is "from hierarchically organized theatre-making" - and thus from the neat linear arcs of text-based, plot-driven narrative - to varieties of "what is generally referred to as 'devising" or "collaborative performance creation [...] with the attendant emphases on physicality and multiplicity (of source material, of form, of discipline, of medium)". ${ }^{14}$

This range of current applications notwithstanding, my argument is that the actual metaphors of texture and weaving could be delved into and followed through more seriously still. Even as they are now being recognized in discourses of new dramaturgy, their philosophical fabric threads back from antiquity to American pragmatism. To argue as much, the following section traces out some of these threads, and dissects the eventness of texture from naïvely mechanistic understandings of spatial "mapping". Subsequently, the notions of textural fusion and spread are used to intuit the eventually "ecological" range of the metaphor - implicit already in Turner and Behrndt's recognition that, in focusing on "the interconnectivity of things in the world", dramaturgical practices may also "have applications beyond drama, or indeed, the theatre". ${ }^{15}$

That this article is, perhaps, infuriatingly woven through with citations is thus justified by its subject matter: when vast underlying metaphors are at issue, attention must be paid to how they are actually used in different contexts and discourses. ${ }^{16}$
That the stakes are ultimately philosophical is already evident in Ingold's distinction between the metaphors of weaving and making, respectively epitomising the "life of lines" that he derives from Gilles Deleuze and Félix Guattari, and their "fragmentation - under the sway of modernity - into a succession of points or dots". ${ }^{17}$ In his latest work, Ingold presents the block and the knot as "mutually exclusive master-tropes for describing the constitution of the world, predicated on philosophies, respectively, of being and becoming" (of building up or carrying on). The challenge is "to consider how a reversion to the knot, after a period during which blocks, chains and containers have remained the paramount figures of thought, could impact on our understanding of ourselves, of the things we make and do, and of the world we live in". If - and this is directly applicable to models of dramaturgy - "the dominant metaphors of block, chain and container [...] lead us to imagine a world comprised of rigid elements", the knot (as the kernel of texture) is distinctly "neither a building block, nor a chain, nor a container". ${ }^{18}$ Such are the metaphorical undercurrents of this article, even as I leave it for the reader to decide if s/he can invest their graphic representation in Figure 1 with meaningful content; further reference to the figure is made when its keywords are cited in italics.

\section{FROM MAPPING TO EVENTNESS: UNWEAVING THE METAPHOR}

On one level, of course, "fabric figures of speech" pervade Indo-European languages. As Stephen Norwick argues, the world's "vital metaphors of spinning, weaving, and knotting" range from the currently mundane - spinning a tale, thread of an argument, fabric of society, moral fiber, biological tissue - to perennial images of nature herself as "a thread, yarn, knot, fabric and chain (of daisies or metal)". Indeed, grand metaphors of the web of life themselves extend from the ancients - with world and destiny alike imagined as a fabric, whether spun by the fates or woven by poets - to the food chains and webs that ground the modern science of ecology. ${ }^{19}$ As for the notion of texture, specifically, its rising theoretical currency is evidenced in a small 
profusion of book-length studies during the last few years, ranging from cognitive poetics and communication technology - Texture as "the experienced quality of textuality" (Stockwell) or as "the weave that binds us in a fabric of interconnection" (Harper) - to organization studies and the entanglement of technology with performance practice. ${ }^{20}$ While by no means new, then, it can be argued that these notions are very much in the air and do serve to undermine overly mechanistic metaphors of design and construction. What I would add, given how the very etymology of texture (from the Proto-Indo-European *teks-, 'to weave, to fabricate, to make') relates it to those of technology, architecture, tectonics and context (the Latin com texere, 'to weave together') is that the notion also implies a "contextualistic" world view, which again implies the eventness of performance, apart from more traditional implications of the term in music, literature and the fine arts. ${ }^{21}$

The specific reference here would be to what philosopher Stephen C. Pepper (1891-1972) has identified as the "root metaphors" of Western aesthetics and epistemology, some of which have already been evoked. If formistic metaphors try to explain what something is like, those of organicism, how this something develops, and mechanistic ones, how it works, then contextualistic metaphors are concerned with how it happens, occurs, or comes about. $^{22}$ (In Figure 1, their suggested associations with chain, braid, space and event are only intended to reflect their core intuitions of form, teleology, location, and texture, respectively. ${ }^{23}$ ) While rarely acknowledged among the likes of John Dewey or William James, Pepper's “contextualistic" elaboration of American pragmatism provides an arguably important precedent to current philosophies of "becoming" and certainly a grounding reference for Morgan's very approach to metaphors of organization.

As articulated in Pepper's World Hypotheses (1942), contextualism names a process ontology of constant novelty and change, taking as its specific root metaphor the "historic event" - not as a thing of the past but "the event in its actuality", "alive in its present $[\ldots]$ when it is going on now, the dynamic dramatic active event" that eventually can only be described by verbs (rather than formal similarities, organic wholes, or mechanical elements). ${ }^{24}$ Further key distinctions are between "the quality of a given event [as] its intuited wholeness or total character" and texture as "the details and relations which make [it] up"; irreducible to hierarchies of content and form or essence and appearance, the two are ultimately intertwined but may also be approached as if they were separate, by way of intuition and analysis respectively. Finally, if "whatever directly contributes to the quality of a texture may be regarded as a strand, whereas whatever indirectly contributes to it will be regarded as context", then which is perceived as which is ultimately a matter of perspective and distance. ${ }^{25}$ No easy divisions of part and whole prevail: where Ingold's ecology of lines admits to "no insides or outsides [...] trailing loose ends in every direction", Pepper's contextualistic world of events admits "no top nor bottom" to its strands and textures $^{26}$ (cf. event in Figure 1).

Accordingly, from some distance, a linear terminology of "strands" appears indeed to pervade the literature on dramaturgy, from the narrative level of storylines and through-lines - dénouements, curves of action, turns of events - to that of "interpersonal relations: filiation, affiliation, marriage tie, liaison, genetic or ancestral line" (for J. Hillis Miller, "line images" are indeed a virtual necessity for even apprehending these). ${ }^{27}$ In the 1930 s, however, the grand theorist of the through-line - Konstantin Stanislavsky - would himself deny having intended "a single line, like a cable", suggesting instead the image of "many lines [...] woven together" - among them the lines of attention, circumstances, events, tasks, actions and control. ${ }^{28}$ In similar terms, Dassia Posner in The Routledge Companion to Dramaturgy has recently presented visual and puppet performance as sporting not only the narrative "interplay of multiple 'strands': words, characters, sounds, or images", but a "fragile thread of belief [...] woven out of things like breath, gaze, surprise, and expectation". ${ }^{29}$

Apart from a general shift from the chain to the braid, in Figure 1, we may observe here a distinct danger regarding the metaphor of texture: that its predominantly visual and tactile connotations might conceal the profoundly multimodal quality it takes on in performance, subsuming and also ho- 
mogenizing this implied variety of strands. This is especially so in contemporary sensor technologies, where lines of movement, touch and speech may equally yield textures of light, sound, or imagery yet the optic is equally applicable to low-tech performance. Just as every "stage figure" is continuously woven together from diverse processes both human and nonhuman, ${ }^{30}$ so also every "acting score" consists in a simultaneity of trajectories often beyond explicit control. Apart from the possibility of each limb enacting divergent choreographies or strips of behavior, the body itself comes down to a bundle of fibres and tissues, metabolically mediated by a constant interchange of heterogeneous materials. ${ }^{31}$

Indeed, one current definition of dramaturgy is as the performative organization of divergent $m a$ terials, considered equally, "in their relationship to one another, rather than breaking them down into separate elements, such as 'character' or 'staging"' (Turner and Behrndt). ${ }^{32}$ However, if such a separation of elements would be a traditionally formistic strategy, the organization of materials can also be imagined in relatively organistic, mechanical, or contextualistic terms (compare the following with Figure 1 again). Where Barba discusses dramaturgy as the layering of such materials, "independently of the performance's meanings", ${ }^{33}$ Mike Pearson would add that these layers, with "different relative thicknesses", will inevitably mediate one another "whether they have natural affinities or not: read onto, into and through each other". ${ }^{34}$ In Barba's ultimately organistic aesthetic, the actors are tasked with "the creation of individual threads", 35 yet "the complexity $[\ldots]$ is attained by working on simple elements [...] put together level by level, interwoven, repeated, until they melt into an organic unity". ${ }^{36}$ In Pearson's "stratigraphic" model, by contrast, dramaturgy consists in arguably more mechanistic acts of assemblage that "obey no hierarchy of text, performer, stage, props and viewing audience". ${ }^{37} \mathrm{In}$ sofar as there is thus a distinct dramaturgy to each of the materials at work, these also figure as unfolding events rather than mere static objects, providing for the kind of contextualistic "thickening" that Tim Etchells describes: "Here - rather than the line A B C D - we have A and also B and meanwhile C, the one running through the other [...] The stage is not so much a sequence as a tangle of diverse intentions. A threading, mirroring, echoing, space. A dramaturgy of knots, collisions, tangles [...] Space is already dramaturgy." ${ }^{38}$

In short, we here proceed from space to event, in the Context section of Figure 1. What is ultimately involved is best clarified by Doreen Massey's theorization of "the event of place" as "the coming together of the previously unrelated", of "constellations of trajectories", of "connections with strands reaching out beyond". Wishing to redeem the notion of space from "the prison-house of synchrony" by redefining it as the "simultaneity of stories-sofar", hers is a crucially "global sense of place" - its contexts inhering in its very texture, its outside as part of its inside, its here-and-now "itself drawing on a history and a geography of thens and theres". In such terms, "arriving in a new place means joining up with, somehow linking into, the collection of interwoven stories of which that place is made [...] picking up the threads and weaving them into a more or less coherent feeling of being 'here', "now'" - "an intertwining of histories" rather than "points or areas on maps", in which "the spatiality of those histories (their then as well as their here) is inescapably entangled". 39

In very similar terms, Tim Ingold also argues that places "do not have locations but histories" and are only contextually brought about "within a wider network of coming and going". ${ }^{40}$ In his world of lines and becoming, "the fundamental principle of coherence" is not building but "knotting". ${ }^{41}$ Conveniently, where a traditional metaphor for the dramaturgy of complication would indeed be of a knot and its unraveling, Ingold suggests that we conceptualize place as well as "a knot of entangled lifelines". Expressing "not an external boundary within which life is contained, but rather the current of life itself as it circles around a focus", the knot "does not contain life but is rather formed of the very lines along which life is lived. These lines are bound together in the knot, but they are not bound by it. To the contrary they trail beyond it, only to become caught up with other lines in other knots", together making up the very texture of the world. ${ }^{42}$ (Cf. space and event in Figure 1.)

Now, what is specifically interesting in such lines 
of argument for our present concerns is how they also seem to render kind of "porous" the cherished idea of theatre or performance as an essentially local art form - not in the sense of advancing some colonial expansion beyond, but in the sense that the alleged beyond already inheres in-the-here: unbound by inherited grids of place and time, the "evental" dramaturgy of a space resides in whatever lines of action or perception enter its ongoing texture. In Ingold's terms, if "containers have insides and outsides" (amounting to the mapping of space in Figure 1), then "the topology of the knot" - or event in the Figure - only consists in "interstices" of which "it is impossible to say what is inside or outside". ${ }^{43}$

However, the tightness of the knot as well as its horizontal effects may still be conceptualized in various ways. For Eugenio Barba, dramaturgical density is due to three different "levels of organisation", such that his own "director's dramaturgy" only consists in "orchestrating the actors' dramaturgies" and "weaving together - through actions - paths of thought" - again to "set in motion the dramaturgy [...] of every spectator". ${ }^{44}$ In a very different line of thought, current emphases on dramaturgy as cultural intervention (if conceivably dating from Lessing and Brecht) range from Bruce Barton's call for an "inter/actual" dramaturgy - "to recognize and work with what a performance is doing, rather than what it is trying to $b e^{\prime \prime 45}$ - to Magda Romanska's tasking dramaturgs with its "contextualization" in audience outreach, from programme notes and lobby displays to previews in social media and theatre apps. ${ }^{46}$

In the concluding section, I will discuss some further variables of context, which, if only implicitly, attend to the one menace of spatial "mapping" that Ingold addresses over and over: "Like a theatrical stage from which all the actors have mysteriously disappeared, the world - as it is represented in the map - appears deserted, devoid of life." ${ }^{47}$

\section{THREADING BEYOND:THE SURPLUS OF CONTEXT}

In the contextual terms I have been arguing for (and it might be advisable to read this with Figure 1 at hand again), we could now suggest that instead of following a pre-given dramaturgy, the work of ac- tions on stage or off constitutes one as it unfolds. "Stretched" beyond imposed teleology, moments of crisis and reorganization also take on a more topological aspect as changes in the overall dramaturgical fabric. While it will usually involve an attempt to orchestrate the attention and expectations of an audience, there is always also a certain surplus to its very eventness that is hard to pin down in any linear structure. By contrast to the Aristotelian idea of Whole Action as a Sequence of Events, eventness can thus be defined as the contextual quality of performance in its unfolding, much of whose "con-texture" will always also leak beyond our direct experience - be it in textures of neural configuration, in the relentless undercurrent of code in digital performance, or, indeed, in the gathering and dispersal of those who co-enact the event (not all of them, necessarily, human).

In Pepper's terms, to reinterpret the linear dramaturgy of beginning, middle and end as the evolution of an ongoing texture as it emerges, is sustained, and then perhaps disperses, is to exemplify the "spread" of events from the immediacy of their textural "fusion" to its contiguous past and future. If indeed, in analyzing a texture, "we move down into a structure of strands and at the same time sheer out into its context", he openly admits that the contextual perspective may equally "contract to a specious present or expand to the speculative limits of [...] world history". ${ }^{48}$ Hence again the earlier distinction of sequence and saturation that now leads us back to the very etymology of "dramaturgy".

To the extent that the word concerns the "work" of actions or the organization of materials, dramaturgy may equally imply the imposition of structure by an author (work on actions) or the work of actions more horizontally, across fields of practice such that dramatic theatre only appears as one case of a more general phenomenon. In the reception end, conversely, this wider ecology tends to remain in tension with its metaphorical elaboration. Even though we quite intuitively reduce the complex eventness of our experience to the cognitively "human scale" of embodied dramatic action, the linearity of the latter remains tacitly entangled in the multiplicity of the former. $^{49}$

In Pepper's terms, such is the work of fusion, ev- 
ident "wherever a quality is had" yet often obscuring its both temporal and textural spread. ${ }^{50}$ Where fusion gives us "unity" (be it of action or character - Ingold's example of the knot), there the spread will confirm its constitutive heterogeneity (Ingold's "proliferation of loose ends" ${ }^{51}$ ). Arguably, the distinctive appeal of the metaphors of texture as I have elaborated them lies precisely in the sheering or zooming between these two perspectives - or, to play with Schechnerian cadences, between intuitions of knot, not knot and not-not knot: up close, the experience of weaving (or knotting, if you are less dexterous like myself) provides more embodied and thus more intuitive metaphors for fusion and heterogeneity than does the immediate organistic alternative established by Deleuzian rhizomatics. Zooming out, however, there is also the counter-intuitive assumption of the "work of actions" as something of a self-weaving web or texture, the implications of which a director like Barba does not always seem at ease with. ${ }^{52}$ Accordingly, I now proceed from problems of "fusion" to the ultimate "spread" that a contextualist perspective will imply.

In his more recent writing, Barba has indeed expressed some concern over his prior metaphor of "weaving". On its arguable implication that "the analysis corresponds to the process" - that the "undoing [of] a woven fabric somehow corresponds" to its weaving - he goes on to suggest that he "should have spoken not of weaving, but of perfume". By this, he means "an intense indivisible unity" into which "the different dramaturgies settle and condense" and which then "acts on the dramaturgy of the spectator"; after the process, its "aromatic essences" can only be extracted by "chemical analysis". ${ }^{33}$ However, there are at least three reasons for still preferring more textural metaphors.

First, what I just evoked as their combination of the intuitive and the counter-intuitive: on the one hand, untying and unweaving are more immediately comprehensible to most than is chemical analysis. On the other hand, Pepper has no problem in also applying his vocabulary of strands and textures to things like chords and savours. (For example, "the quality of lemonade" involves strands of lemon, sugar and water, which may, however, "take on qualities of their own" once their "persistent fusion
[...] is relaxed". $\left.{ }^{54}\right)$ Second, apart from downplaying texture for an intuition of pure quality, Barba's notion of perfume as a unity of essences is closer, in Ingold's terms, to a tightly-filled container of metaphorical substance than to a knot or weave of ongoing processes - and it seems very introvert in its unity, indifferent to what sorts of strands each given viewer would either bring in or follow through and to what kinds of further textures. Third, the process and analysis of weaving will not "correspond" quite as Barba suggests. In claiming as much, his implicit appeal is again to a more "articulated" structure like a chain, which Ingold poetically argues has "no memory of its formation": "When you release the tension in a chain and let it fall to the ground, it comes to rest in a disordered heap. But if you untie a knotted rope, however much you try to straighten it, the rope will retain kinks and bends and will want, given the chance, to curl up into similar conformations as before." ${ }^{55}$ (Cf. chain and braid in Figure 1.)

With these notions of fusion, diffusion and memory, we effectively return to those of perspective, as well as to organization studies, where Robert Cooper and Stephen Fox have fruitfully discussed Pepper's concept of texture in terms of weaving and glossing, the implicate and the explicate, the tacit and the explicit. As "a weave or web of interacting elements that resists operational definition", the "tacit aspect of texture" names for them "a form of uncontrollable excess which can only be glossed over". Where "weaving recognizes the implicit tendency of texture to transgress socially contrived meaning", such "glossing practices give a seeming definiteness to what is really provisional, a comforting integrity to what is incomplete". ${ }^{56}$ In Ingold's gloss, the resultant explicate order "imagines a world of individual entities and events, each of which is linked through an external contact - whether of spatial contiguity or temporal succession - that leaves its basic nature intact". In the implicate order of texture and weaving, by contrast, each phenomenon "enfolds within its constitution the totality of relations of which, in their unfolding, it is the momentary outcome" ${ }^{57}$ (In Figure 1, these categories are connected to chain/space and braidlevent, respectively.)

In short, any beginnings and endings will only 
ever appear from the outside and after. What in one modality only appears as the tacit weaving of an ongoing texture (say, of the sounds and trajectories of those acting or not in a specific time and place) is easily glossed, in the other, into a sequence of events driven by allotted intentionalities; while the strands of the former need not all be of a kind nor necessarily fluid (as in post-modern theory), whatever patterns they take will depend on distance and perspective. In Pepper's terms, this spells the relativity of strand, texture, and context, each assuming the qualities of the other according to pragmatic orientation: up close, there is a texture to every strand, while whole textures may appear as mere strands from afar. ${ }^{58}$ In Ingold's terms, the distinction is between the implicate order of the knot (its "constitutive strands" bound into others "as they extend beyond it"), and the explicate order of the block, as each is "joined to the other by external contact or adjacency" 59 (cf. event and chain in Figure 1).

I am not suggesting here a hierarchy of value, with all linear dramaturgies - readily conceived as arcs of scenes or chains of blocks - now subordinate to some vague vision of textural becoming; indeed, zooming out to such tentative analytical patterns is a virtual necessity in both art and life, given the very limitations of human memory. Rather, I point toward an experiential duality, in which whatever "vision" we may gain over the texture of events can only remain vague, while the texture itself keeps weaving on. Within this "spread" of texture lies also a sense of "context" that may not be readily apparent, but whose implications are significant enough to draw out in conclusion.

As psychologist Edward Morris puts it, connotations of "background, circumstances, conditions, framework [...] emphasize context-as-place, not context-as-history" which is the specific root metaphor intended by Pepper and also assumed by Dewey. ${ }^{60}$ Where the former connotations lend themselves to procedures of spatial mapping, context is not about containment here, nor is texture primarily a function of its surface; conceived as a strictly evental rather than a spatial term, context is constitutively inherent in every texture rather than providing some external "frame" to its references.

The difference is delicate, yet it points to signifi- cant metaphorical assumptions that easily go unnoticed. While Willmar Sauter would agree that the relevant contexts of the "theatrical event" not only reside in its background but "are constantly present" therein, his original graph, however, depicts them from the closest spheres of convention and conception to the wider cultural life world further on out (space in Figure 1) ${ }^{61}$ In Pepper's view, by contrast, a properly contextual notion of eventness should conceive of context not on the image of concentric containment, but in terms of the fluid intertwining of its divergent layers or strands - not as a mere mapping of readymade entities, embedded in readymade contexts, but through a more evental cartography of ongoing processes, constitutively interwoven with their ongoing contextures (event in Figure 1). To rephrase well-worn idioms of the content being in the form, or the medium being the message, we might thus suggest that whatever the medium - art form or life form - its meaning resides in the ecology of its weaving, going on and leaking beyond.

Hence, then, the widest "context" that has been implicit throughout, beginning from Turner and Behrndt's observation that "dramaturgy concerns the interconnectivity of things in the world". ${ }^{62}$ For Ingold, seeking not to convert the threads "along which life is lived into boundaries within which it is contained" (as in the "logic of inversion" 63 he finds central to modern thought), ecology names "the study of the life of lines", which again is "virtually impossible to accommodate [...] within some neatly ordered system" as indeed such lines of life "always seem to wriggle free of any classification one might seek to impose on them, trailing loose ends in every direction" ${ }^{64}$ Arguably, it is this trailing precisely that constitutes a key image not only to "the ecological thought" recently defined in like terms by Timothy Morton, ${ }^{65}$ but also to the contextualist world view outlined by Pepper in 1942 . Where Morton relates our ecological interconnectedness to "thinking big as big as possible" (to "magnitude beyond any idea of magnitude", 66 beyond Aristotle's notions of the proper organic magnitude of tragedy), the scope of Pepper's contextualistic world is ultimately "dispersive" as well. If the ecological thought is "intrinsically open, so it doesn't really matter where you begin" - it "permits no distance", its "here is shot through 
with there" ${ }^{167}$ - so also the contextualist casts part and whole, the small and the big as thoroughly implicated in each other. Indeed, it is the "sheering character" of tracing out the strands at hand that defines Pepper's pragmatist epistemology: on the one hand, "you never reach the end of it", on the other, any event can be analyzed in "many equally revealing ways $[\ldots]$ depending simply on what strands you follow from the event into its context" ${ }^{68}$

In summary, then, this article has discussed mapping and texture as figures of spatiality and eventness, across relatively local and global models of dramaturgy and ecology. In Figure 1, mapping would be related to the explicate order of Pepper's formistic and mechanistic world views, exemplified by corresponding models of dramaturgy (as a chain of discrete events) and context (as a spatial embedding of discrete locations). By contrast, the metaphors of texture or weaving characterize the implicate order of Pepper's organicism and contextualism, and hence the conceptions of dramaturgy as a varying braid of actions, and of context as the interweaving of open-ended events. Taking a final cue from Pepper himself, if contextualism is "sometimes said to have a horizontal cosmology in contrast to other views, which have a vertical cosmology", it is because "the analysis of an event consists in the exhibition of its texture, and the exhibition of its texture is the discrimination of its strands, and the full discrimination of its strands is the exhibition of other textures". ${ }^{69}$ In other words, where other forms of analysis aim at the top or bottom of things - be it in discrete forms, organic wholes, or mechanical parts - contextualist analysis proceeds in the thick of things, as it were, picking from the scene at hand only the strands of immediate pragmatic concern (whether the proper context of analysis is aesthetic, psychological, or cultural, for example, or perhaps precisely the "interweaving of performance cultures"70). While I am not suggesting that other orientations are devoid of value - indeed, I have elsewhere emphasized the value of the "explicate" to the very quality of theatricality ${ }^{71}$ - considering these models at least has the function of sensitizing the scholar or researcher to underlying metaphorical assumptions which otherwise might go unnoticed. 


\section{NOTES AND REFERENCES}

1 Gareth Morgan, Images of Organization, Sage, Thousand Oaks 1997, p. 4.

2 Cathy Turner, Synne K. Behrndt, Dramaturgy and Performance, Palgrave Macmillan, Basingstoke 2008, pp. 21-2.

3 Ibid., pp. 21, 31-3; Eugenio Barba, On Directing and Dramaturgy. Burning the House, Routledge, London, New York 2010, p. 9; Eugenio Barba, "The Nature of Dramaturgy. Describing Actions at Work" in New Theatre Quarterly, vol. 1, no. 1, 1985, p. 76.

4 Turner, Behrndt, op. cit., p. 5.

5 Tim Ingold, Lines. A Brief History, Routledge, London, New York 2007, pp. 152-5.

6 Doreen Massey, For Space, Sage, London 2005, pp. 28, 31, 100, 106-7.

7 Tim Ingold, The Perception of the Environment. Essays in Livelihood, Dwelling and Skill, Routledge, London, New York 2000, pp. 226-7, 230.

8 Ingold, Lines, op. cit., pp. 74.

9 Richard Schechner, Between Theater \& Anthropology, University of Pennsylvania Press, Philadelphia 1985, pp. 140-1.

10 Barba, "The Nature of Dramaturgy", pp. 75-6, 78.

11 Ingold, The Perception of the Environment, op. cit., p. 346.

12 See e.g. the special journal issues "On Dramaturgy" and "New Dramaturgies" of Performance Research (vol. 14, no. 3, 2009) and Contemporary Theatre Review (vol. 20, no. 2, 2010) respectively.

13 Claire MacDonald, "Conducting the Flow. Dramaturgy and Writing" in Studies in Theatre and Performance, vol. 30, no. 1, 2010, pp. 94, 96.

14 Bruce Barton, "Interactual Dramaturgy. Intention and Affect in Interdisciplinary Performance" in The Routledge Companion to Dramaturgy, Routledge, London, New York 2014, p. 179.

15 Turner, Behrndt, op. cit., p. 36.

16 For more on the complexities of theatrical metaphors, see Teemu Paavolainen, "Textures of Thought. Theatricality, Performativity, and the Extended/Enactive Debate" in The Cognitive Humanities: Embodied Mind in Literature and Culture, Peter Garratt, ed., Palgrave Macmillan, Basingstoke (forthcoming).

17 Ingold, Lines, op. cit., p. 75.

18 Tim Ingold, The Life of Lines, Routledge, London, New York 2015, pp. 15, 22.

19 Stephen A. Norwick, The History of Metaphors of Nature.
Volume I. Science and Literature from Homer to Al Gore, Edwin Mellen, Lewiston 2006, pp. 343-457.

20 Peter Stockwell, Texture. A Cognitive Aesthetics of Reading, Edinburgh University Press, Edinburgh 2009; Richard Harper, Texture. Human Expression in the Age of Communications Overload, The MIT Press, Cambridge, MA 2010; Silvia Gherardi, Organizational Knowledge. The Texture of Workplace Learning, Blackwell, Malden, MA 2006; Chris Salter, Entangled. Technology and the Transformation of Performance, The MIT Press, Cambridge, MA 2010.

21 On the musical use in relation to the history of theatre directing, see Teemu Paavolainen, "Woven Within. Textures of Theatricality and the Directorial Impulse" in Tekijä. Teos, esitys ja yhteiskunta. Näyttämö \& tutkimus 6, Annette Arlander, Laura Gröndahl, Helka-Maria Kinnunen, Marja Silde, eds, Teatterintutkimuksen Seura, Helsinki (forthcoming online at <http://teats.fi/julkaisut. html>).

22 Stephen C. Pepper, World Hypotheses. A Study in Evidence, University of California Press, Berkeley, CA 1984 [1942], pp. 151-85, 280-314, 186-231, 232-79.

23 To exemplify, spatial location is central to Pepper's understanding of mechanism in the sense that not only is the "functioning of the machine" determined by the "configuration of [its] parts" (his basic example being the lever), but so is the very "reality" of things certified by their "particularization [...] in a line, or path, or volume of these locations": "An object is where it is, says the mechanist" (ibid., pp. 191, 197-9).

24 Ibid., p. 232.

25 Ibid., pp. 238, 246 (my italics).

26 Ingold, Lines, op. cit., pp. 103, 50; Pepper, op. cit., p. 251.

27 J. Hillis Miller, Ariadne's Thread. Story Lines, Yale University Press, New Haven 1992, p. 20.

28 Quoted in Sharon Marie Carnicke, Stanislavsky in Focus, Routledge, London, New York 2008, p. 2.

29 Dassia Posner, "The Dramaturg(ies) of Puppetry and Visual Theatre" in The Routledge Companion to Dramaturgy, Routledge, London, New York 2014, p. 335.

30 See Teemu Paavolainen, Theatre/Ecology/Cognition. Theorizing Performer-Object Interaction in Grotowski, Kantor, and Meyerhold, Palgrave Macmillan, New York 2012, pp. 42-3.

31 See Tim Ingold, Being Alive. Essays on Movement, Knowledge and Description, Routledge, London, New York 2011, pp. 28, 86-7. 
32 Turner, Behrndt, op. cit., p. 34.

33 Barba, On Directing and Dramaturgy, op. cit., p. 9.

34 Mike Pearson, Site-Specific Performance, Palgrave Macmillan, Basingstoke 2010, pp. 167-8.

35 Barba, On Directing and Dramaturgy, op. cit., p. 204.

36 Eugenio Barba, "An Amulet Made of Memory. The Significance of Execises in the Actor's Dramaturgy" in The Drama Review, vol. 41, no. 4, 1997, p. 131.

37 Mike Pearson and Michael Shanks, Theatre/Archaeology, Routledge, London, New York 2001, p. 101.

38 Tim Etchells, "Doing Time" in Performance Research, vol. 14, no. 3, 2009 , p. 78.

39 Massey, op. cit., pp. 36, 119, 130-1, 138-41, 153, 1878.

40 Ingold, The Perception of the Environment, op. cit., pp. 219, 227.

41 Ingold, Life of Lines, op. cit., p. 14.

42 Ingold, Lines, op. cit., pp. 99-100.

43 Ingold, Life of Lines, op. cit., p. 15.

44 Barba, On Directing and Dramaturgy, op. cit., pp. 10, $57,123,13$.

45 Barton, op. cit., p. 184.

46 Magda Romanska, "Introduction" in The Routledge Companion to Dramaturgy, Routledge, London, New York 2014, pp. 10-11, 13.

47 Ingold, The Perception of the Environment, op. cit., p. 234.

48 Pepper, op. cit., pp. 250, 279.

49 Cf. Paavolainen, “Textures of Thought", op. cit.

50 Pepper, op. cit., pp. 239-46.

51 Tim Ingold, Making. Anthropology, Archaeology, Art and Architecture, Routledge, London, New York 2013, p. 132.

52 On the metaphorical principles implied, see Paavolainen, Theatre/Ecology/Cognition, op. cit., p. 38.

53 Barba, On Directing and Dramaturgy, op. cit., pp. 204-5.

54 Pepper, op. cit., p. 243.

55 Ingold, Life of Lines, op. cit., pp. 15, 25.

56 Robert Cooper and Stephen Fox, "The 'Texture' of Organizing" in Journal of Management Studies, vol. 27, no. 6, 1990, pp. $575,588$.

57 Ingold, Being Alive, op. cit., p. 236. The "explicate" and the "implicate" are freely adapted from physicist David Bohm, Wholeness and the Implicate Order, Routledge, London, New York 1980.

58 Pepper, op. cit., p. 248.

59 Ingold, Life of Lines, op. cit., p. 15.

60 Edward K. Morris, "Some Reflections on Contextual- ism, Mechanism, and Behavior Analysis" in Psychological Record, vol. 47, no. 4, Fall 1997.

61 Willmar Sauter, The Theatrical Event. Dynamics of Performance and Perception, University of Iowa Press, Iowa City 2000, pp. 9-10.

62 Turner, Behrndt, op. cit., p. 36.

63 See Ingold, Being Alive, op. cit., pp. 68-70.

64 Ingold, Lines, op. cit., pp. 2, 103, 50.

65 Timothy Morton, The Ecological Thought, Harvard University Press, Cambridge, MA 2010.

66 Ibid., p. 20.

67 Ibid., pp. 12, 39, 52.

68 Pepper, op. cit., pp. 252, 250.

69 Ibid., pp. 249, 251.

70 This is the key metaphor recently cultivated by Erika Fischer-Lichte: "Many strands are plied into a thread; many such threads are then woven into a piece of cloth, which thus consists of diverse strands and threads [...] dyed, plied and interwoven [...] without allowing the viewer to trace each strand back to its origin." (See her "Introduction" in The Politics of Interweaving Performance Cultures. Beyond Postcolonialism, Erika Fischer-Lichte, Torsten Jost, Saskya Iris Jain, eds, Routledge, London, New York 2014, p. 11-12.)

71 See Paavolainen, "Textures of Thought”, op. cit.; Paavolainen, "Woven Within", op. cit. 